\title{
Selected Factors of SMEs Management in the Service Sector
}

\author{
Belas, Jaroslav \\ Tomas Bata University in Zlín, Zlín, Czech Republic \\ Amoah, John \\ Tomas Bata University in Zlín, Zlín, Czech Republic \\ Petráková Zora \\ Slovak University of Technology, Bratislava, Slovak Republic \\ Kljuchnikava, Yana \\ Tomas Bata University in Zlín, Zlín, Czech Republic \\ Bilan, Yuriy \\ Sumy State University, Sumy, Ukraine
}

Received: 15 September 2020. Revision received: 23 October 2020. Accepted: 2 November 2020

\begin{abstract}
The article aims to compare important management factors between SMEs in the service sector and SMEs in other entrepreneurship sectors. The study was realized in the Czech Republic and the Slovak republic over SMEs in the service sector and other sectors in 2019-2020. The data were collected from the owners or top-level managers; the total sample used in the study was 822 SMEs. The questionnaire was constructed in an online version and was fulfilled by 240 SMEs in the service sector and 582 other companies in the Czech or Slovak republic. The research hypotheses were evaluated by basic statistics tools: contingency tables, Z-score, and Chi-square test. The results showed that there are significant differences in the agreed attitudes to the statement: "I manage the company for more than 8 hours a day" between the Czech (62\%) and Slovak (71\%) respondents in the service business sector. Neither nationality nor the business sector is essential determinants in the perception of human capital as the most critical element in the company (8 out of 10 respondents) and the fact that the owner (manager) of the company should regularly evaluate the performance of its subordinates and motivate them to innovate in work processes. The results are interesting for the entrepreneurs themselves and for entities and organizations that help SMEs' business activities in selected countries, respectively, for economic policymakers.
\end{abstract}

Key Words: small and medium enterprises, service sector, management, management style, human resources

JEL Classification: M12, L80, N70

Reference: Belas, J., Amoah, J., Petráková, Z., Kliuchnikava, Y., Bilan, Y. (2020). Selected Factors of SMEs Management in the Service Sector. Journal of Tourism and Services, 21(11), 129-146. doi:10.29036/jots.v11i21.215

\section{Introduction}

Management is a distinct and essential function that determines the viability and success of the firm. Managing the service sector concerning the small and medium-sized enterprises (SMEs) has become very competitive due to the numerous ways or styles that a particular manager or country adopts to operate with and the current dynamism of the environments (Pisar \& Bilkova, 2019). Global competitiveness has been one of the major factors contributing to the increased need for innovation and 


\section{JOURNAL OF TOURISM AND SERVICES}

Issue 21, volume 11, ISSN 1804-5650 (Online)

www.jots.cz

adaptation in several business fields (Dima et al., 2018). It is implied in management and business models as well (Tanţău et al., 2018).

According to Mensah (2004), enterprises are generally characterized as controlled by one individual, with almost all major decisions taken by the proprietor or the owner. Thus, SMEs often face management problems. There are poor strategic plans for the development of the enterprise due to the lack of managerial skills of the entrepreneurs, especially in the field of business risk management (Hudakova et al., 2018; Belas et al., 2018, Kljucnikov et al., 2016; Kozubíková et al., 2015) are among them. There is also highly volatile working capital and difficulty accessing finance (Rahman et al., 2018; 2017), some barriers for innovations (Hvolkova et al., 2019). They use archaic technology and depend on manual labor, and they mostly resort to unpaid labor (Priem et al., 2012). The success of SMEs also depends on the current situation in the labor market (Koyšová et al., 2018).

In view of this, management is seen as a distinct function within an SME enterprise's organization. SMEs play an essential role in the economic development of the country. Therefore, the definition of management of an enterprise has become difficult with regards to each country's point of view in terms of employment, the value of assets, annual turnover, and paid-up capital (Soomro \& Aziz, 2015).

Many countries in the world find it difficult as to why enterprises' service sector keeps declining due to its sustainability and growth rate and therefore spending vast sums of money across the globe to conduct a study (Bilan et al. 2017; Soomro \& Aziz, 2015). A business can increase success in any economic activity using global know-how and local resources (Brătianu \& Anagnoste, 2011; Păunescu, 2014). There is, therefore, a need to conduct this study, which will help in managing the service sector of the enterprise (SMEs). According to Soomro \& Aziz (2015), enterprises have common benefits when properly managed to both national(countries) and international institutions. Therefore, these institutions would determine if financial or management services support to the enterprises would help them significantly towards their countries' growth.

According to resource-based theory, owner-managers of small and medium-sized enterprises (SMEs) often lack internal resources to face various economic challenges such as management of the service sector and rely on external services providers (De Bruyckere et al., 2020; Çera et al., 2019).

Concerning the increasing number of enterprises in the Czech Republic and Slovakia, a sizable number of research works and publications have been authored for the management of enterprises and service sectors, leaving out the factors that account for the failure of managing the service sector enterprises. To the present authors' knowledge, few research works have been done without considering the two countries' comprehensive comparative analysis. Therefore, this study aims to make a comprehensive comparison of the two countries of what factors exactly account for enterprises' service sector management.

The present study seeks to add to existing literature and fill the research gap in the following ways: (1) the factors which are influencing the management of enterprise complying the two countries that is the Czech Republic and Slovakia and (2) the factors that seek to affects the management of service sector enterprise with regards to the above two countries. Above all, the study would benefit the existing and new industry players to adopt new managerial skills to help them in the service sector enterprise.

The remaining part of this paper is structured as follows: the second part is dedicated to the literature review, developing the research hypotheses and clarifying the covariates which make two groups comparable; the third part deals with methods and procedures, including measurement of variables, sampling and data collection, the statistical tests and matching methods; the results are presented in section four, and the discussion and concluding remarks are dealt with in section five.

\section{Literature review}




\section{JOURNAL OF TOURISM AND SERVICES}

Issue 21, volume 11, ISSN 1804-5650 (Online)

www.jots.cz

\subsection{Management of SMEs}

Ever since people began to form groups to achieve goals that they could not achieve alone, management has been essential to ensure the coordination of individual's efforts.

According to Kwaku Amoah (2018) and Lewandowska and Stopa (2019), SMEs are seen as contributors to socioeconomic growth based on the significant impacts in increasing the gross domestic product, innovation, and entrepreneurship. As SMEs serve as an engine contributing to the economy, its management becomes a critical issue. Management of SMEs is defined as the process whereby the firm's entrepreneurs or owners rely on the current and past working experience derived from other working environments or places, skills, and exposures acquired to manage the firm (Mamabolo \& Myres, 2020; Meyer et al., 2018). Project management practice has a significant impact on annual turnover and number of employees dynamics not only in private companies but in social enterprises as well (Kubíčková \& Hodžić, 2019).

Often, SME managers do not have sufficient awareness of managing the firm's processes during unforeseen business circumstances. They need to realize the scale of the ongoing technological and informational changes in the market, act proactively, and use all possible resources, that is, dynamically adapt their behaviour (Pratono, 2016).

In this article, it is intensely debated that the problem of SMEs management can be solved by acquiring adequate skills and knowledge. Skills are defined as the application of knowledge through direct observation to execute a task or solve a problem (Marvel et al., 2016; Mishchuk et al. 2016; Mačerinskiené \& Survilaite, 2019). Research on SME management can be guided through human capital theory (Becker, 1994), which states that individual workers have a set of skills or abilities that can be improved through training and education (Gluchman, 2018). This theory takes into account such components of personal qualities as knowledge, skills and personality (Awiagah et al., 2016; Hayton \& McEvoy, 2006 and Isonzo, 2006). At the same time, it argues that small and medium-sized enterprises entrepreneurs should use the abilities of an individual or employee to performing various responsibilities in the field of activity.

One of the major challenges comforting SME management currently is technological and managerial innovation. They are an essential determinant of economic development not only from the point of view of the microsphere but also in the evaluation of macroeconomic development and forecasting of economic cycles of countries (Behun et al. 2018). In the literature, it was also concluded that SMEs could be managed adequately by paying critical attention to those dual keys mentioned above and making sure it is properly introduced to the organisational system of SMEs (Žufan et al., 2020; Cieślik \& Michałek, 2018; Kot et al., 2019; Bocconcelli et al., 2017; ). One of the studies conducted suggested that most SMEs generally lack the skills of information and communication technology (ICT) in its management of the organisation (Ion \& Andreea, 2008; Androniceanu \& Tvaronavičiené, 2019). Currently, the use of information and communication technology cannot be overlooked regarding the role been played by this key factor (Ion \& Andreea, 2008; Zadorozhnyi et al., 2018). However, when critical attention is paid to the use of information communication technology, SME management can be easier since it improves the managerial processes and practices.

\subsection{Employees in Participation Management Styles}

Different management styles are practised by managers of SMEs to enhance individuals and collective efficiency of employees (Nadeem, 2012; Ključnikov et al., 2019). "Participation is a process by which influence is shared among individual who is otherwise hierarchical unequal" (Zia \& Nouman, 2014). In the same literature, participation management style was defined as a practice whereby managers involve individuals or subordinates in taken decisions or addressing problems confronting the organisation, information sharing and processing. From the above literature, it was concluded that participation management style could serve as a tool in solving SMEs management problems. However, it was argued that the impact of participative decision making on organisations could not be overlooked. 


\section{JOURNAL OF TOURISM AND SERVICES}

Issue 21, volume 11, ISSN 1804-5650 (Online)

www.jots.cz

In the management process, it is crucial to avoid the appearance of too many variations, as well as to emphasise the understanding of the task by all participants in the management (Zhang et al., 2017).

However, a group of researchers have shown that a participative management style has been defined as joint decision-making between supervisors and employees offers a potential benefit to the organisation and its employees. It was therefore agreed that involving employees in participative management also enhances the capabilities and skills of the employees, increase in social and mental demands and above all pose a responsibility for others to collaborate (Nadeem, 2012; Day et al., 2005; Geberth et al., 2003; Gluchman, 2019). Zhang et al. (2017) argue that it is essential for SMEs to focus on the learning organisation to develop employee innovation, emphasise teamwork, and improve management through exploitative learning. Improvements in management should be results-oriented. Similar published research state that participative management practices are often perceived as a wide range of variety of potential benefits for the organisation which shapes the organisational employees mental and job satisfaction (Argyle \& Lu, 1990; Mikalauskas et al., 2019).

\subsection{Employees in Decision-Making of SMEs}

Involving employees in decision-making has always become a challenge for managers, especially SMEs, since it requires risk on the part of the management (Spreitzer \& Mishra, 1999). In the said literature, employees with specialisation are seen to perform better when involved in the decision-making of the organisation because they filed like they are part of the management.

However, in the works of (Nadeem, 2012; Leake et al., 1998), it was observed that when employees are well involved in the decision-making process with regards to setting goals, developing work schedules or job rotations, delegate authority, gives the organisation a sense of hope of sustainability in the area of its management and performance. However, the involvement of employees in decisionmaking brings about the feeling of "we" are part of the management and hence makes it a positive relationship between management and employees (Rozsa et al., 2019; Nadeem, 2012; Zia \& Nouman, 2014).

A firm's performance in the literature is often reflected in the value-added per employee. Due to the small size of an SME, all employees need to be proactively involved and fulfilled to be successful. To involve an employee in decision-making, increase his proactivity, and attract to cooperation with colleagues, SMEs can use various pay for performance bonuses. By the way, cooperation is one of the most important factors in the success of an SME (Wanget al., 2016). When employees are involved in a decision-making process, the issue of understandability improves in the organisation because people are more committed to duties or actions when they are really involved in the process. Employees pay less attention to competition in the workplace and more to collaborative at work on joint goals or objectives and also a social commitment to each other is increased as a result of decision-making involvement (Nadeem, 2012). The involvement of employees often brings about a positive impact on the organisation in the area of maximising profit and growth (Andersén, 2017; Wach et al., 2016). Staff turnover can be a significant risk for SMEs. When employees who are the most educated and qualified in their field leave the workplace, SMEs, due to their small size, cannot always make up for the lack of knowledge and train a new employee in time. Therefore, maintaining employee loyalty and loyalty is an essential task (Rozsa et al., 2019). That is why managers of SMEs have identified the occupational well-being of its employees as a contributing factor that influences their conduct in the organisation (Andersén, 2017).

\subsection{Performance Evaluation of SMEs Management}

Many SME's managers encounter different problems as to how employees are evaluated in the area of performance. Good management and perception of talent risk can help improve the efficiency and productivity of an SME. Many entrepreneurs are dissatisfied with employee performance, which only means that there are significant gaps in how managers drive and manage employee performance 


\section{JOURNAL OF TOURISM AND SERVICES}

Issue 21, volume 11, ISSN 1804-5650 (Online)

www.jots.cz

(Kotaskova et al., 2020). Ahmed et al. (2013) defined employee performance evaluation as the assessment of employees or workers through the use of different types of data in their decision-making. In the said literature, performance evaluation serves as a potential tool for effective and efficient management of the organization's human resources and evaluation of staff that help develop individuals, improve organizational performance, and feed into business planning.

Additionally, most SMEs managers in assessing employees' performance use a manual approach, which stands the chance of been bias and therefore proposed the use of modern and efficient internetbased systems in its evaluation of employees (Kaur \& Sood, 2017). The proper use of a modern and efficient approach to assessing employees makes the management of SMEs easier. So far, minimal literature exists on SMEs employees' performance evaluation, which therefore calls for new research in this area.

Moreover, employee performance evaluation in Cengiz Toklu \& Taşkin, (2017) "identified the gap between expected and existing performance, performance improvement opportunities and supporting continuous improvement, providing information for long-term decisions and enabling interaction between processes and stakeholders." It calls for a proposal of flexible, dynamic and practical performance evaluation tool from management and organization viewpoint for SMEs. Performance of the SMEs also depends on the structure of the service sector. As in the case of Taiwan, knowledgeintensive business services register a high level of productivity and profitability (Chung \& Tseng, 2019).

\subsection{Human Capital in SMEs Management or Service Sector}

The mention of human capital as an essential element of SMEs or management of the service sector can be found already in the 18th century: Adam Smith defined it as the economic value of an employee's experience and skills. "This economic value or asset includes education, skills, intelligence, health, and other employee values such as loyalty and punctuality" (Kenton, 2019). The presence of these factors affects the overall management and performance of an organization or service sector (Muda \& Rahman, 2016).

One can also find the definition of human capital as the knowledge, skills and experience of employees, as well as a decisive element in the process of transforming information into valuable knowledge that will improve the results of the firm's performance and, therefore, are considered intangible resources for the firm. Human capital is seen in three main categories: capability and potential, motivation and commitment and innovation and learning. "Capability and potential referral to the educational level, professional skills, experience, attitudes, personal networks, values, and the ability of current employees to evolve within the organization. Motivation and commitment refer to whether employees align their interests with those of the firm, while innovation and learning show the degree to which employees are open to change" (Muda \& Rahman, 2016).

With the help of human capital, companies can create and develop organizational structure and strategy. R\&D and human resources can be used to improve the impact of brand equity on a company's profitability, although as noted by He et al. (2019), the effectiveness of such use may be negligible in nonstate companies and companies in the service sector. It is noted that the quality of the SME business environment also depends on human capital - quality employees trained to work in this area (Kotaskova \& Rozsa, 2018). As an example of the positive impact of developed human capital on SMEs in the service sector, we can cite the Sardo et al. (2018) research, from which it follows that the financial performance of hotels and the tourism industry, in general, directly depends on the experience and skills of employees.

Developed human capital is strategically important and valuable to the firm. Improving human capital can be achieved through one-to-one training, organizing training events, training and skills development to encourage the exchange of knowledge, experience and know-how between employees and customers (Muda \& Rahman, 2016; Ferreira \& Franco, 2019). It is noted that there is a relationship between the influence of human capital on the success of the firm and how the knowledge of managers/owners of SMEs was obtained. Interestingly, some courses may not be helpful in staff 


\section{JOURNAL OF TOURISM AND SERVICES}

Issue 21, volume 11, ISSN 1804-5650 (Online)

www.jots.cz

development if they are not related to practice or personal experience. The author also argues that previous work experience has a positive effect on productivity but does not have much of an impact on profitability (Soriano \& Castrogiovanni, 2010).

The development of human capital plays an important role in building the management of an organization. For example, innovativeness is an essential determinant of entrepreneurial orientation in the service sector (Hernández-Perlines et al., 2019). Innovation leads to proactive and risky behaviour by managers. The literature notes that some SMEs are increasingly investing in intellectual capital, which is continuously associated with an increase in the innovative activity of the firm. These actions are relevant in the modern competitive market of developed countries, which differs in that it is achieved not by reducing costs, but through innovation (Agostini et al., 2017).

\section{Aim, Methodology, Methods And Data}

The article aims to compare important factors of management between SMEs in the service sector and SMEs in other sectors of entrepreneurship. A comparison between selected groups of SMEs is provided separately in the Czech business environment and the Slovak business environment. This topic was a part of extensive research of the management, business risks and bankruptcies in the SMEs conducted at Tomas Bata University (and other partners' universities) in period 2019-2020.

The random selection method based on the mathematical function "Randbetween" was used to select SMEs from "CRIBIS" in both countries. Subsequently, SMEs were addressed via an email requesting to fulfil out an online questionnaire. The questionnaire was intended for the owner or the top managers of SME (hereinafter referred to as "respondents"). The response rate in the Czech Republic was approx. 5.7\% (the number of addressed entrepreneurs was more than 8000 ). The number of addressed businesses in the Slovak Republic was more than 10 000. The response rate of completed questionnaires was approx. $3.7 \%$.

The questionnaire covered (77questions): a) basic characteristics of entrepreneurs and their enterprise- the locality of entrepreneurship (region of residence), the sector of the economy; the size of the enterprise; the type of enterprise; gender; age and the level of education of an entrepreneur; b) enterprise risks assessment - market risk, strategic risk, financial risk, personal risk, legal and operational risk; c) risk management - how do respondents identify and quantify risks in their company; d) the attitudes of respondents of statements of the bankruptcy of small and medium-sized enterprises. We have managed to collect the total of $822(100 \%)$ fulfilled questionnaires, 454 of them were from the Czech enterprises (55.2\%), and 368 were from their Slovak enterprises (44.8\%).

The questionnaire was created in two versions according to the nationality of the respondent. Slovak version is available at https://forms.gle/ raX3qYeqrcqRFeAF6, and the Czech version is available at https://forms.gle/okjZypAru4BpSHFb8

The respondents could comment on the management risk (MR) and their sources (MR1, MR2, MR3 and MR4) by one of the following answers: I strongly agree (answer - A1), I agree (A2), I neither agree nor disagree (A3), I disagree (A4), and I strongly disagree (A5). The sources of the management risk are:

MR1: I do business (manage a company) intensively (more than 8 hours a day).

MR2: I apply a participative management style (involving employees in decision making).

MR3: I consider human capital in the company as the most important one.

MR4: The business owner (manager) should regularly evaluate the performance of their subordinates and motivate them to innovate workflows.

The authors formulated the following null statistical hypotheses:

H1: There are significant statistical differences between attitudes of respondents on the selected sources of the management risk in the Czech Republic (H1_CR) and in the Slovak Republic (H1_SR). 


\section{JOURNAL OF TOURISM AND SERVICES}

Issue 21, volume 11, ISSN 1804-5650 (Online)

www.jots.cz

H2: The business sector is no significant statistical factor of evaluating the source of management risk (H2_MR1, H2_MR2, H2_MR3 and H2_MR4) between respondents of the Czech enterprises.

H3: The business sector is no significant statistical factor of evaluating the sources of management risk (H3_MR1, H3_MR2, H3_MR3 and H3_MR4) between respondents of the Slovak enterprises.

H4: The business sector is no significant statistical factor of evaluating the positive attitudes on the sources of management risk (H4_MR1, H4_MR2, H4_MR3 and H4_MR4) between respondents of the Czech enterprises.

H5: The business sector is no significant statistical factor of evaluating the positive attitudes on the sources of management risk (H5_MR1, H5_MR2, H5_MR3 and H5_MR4) between respondents of the Slovak enterprises.

In the first step, contingency tables were used to evaluate the formulated research hypotheses $(\mathrm{H} 1, \ldots \mathrm{H} 5)$ in order to classify the attitudes of the respondents according to the type of answer (A1, .., A5) and the characteristics of the respondents (nationality: CR, SR and business sector: service companies (SC) and other companies (OC)). The number of companies is expressed in absolute terms (number of respondents) and relative (percentages). Hypotheses $\mathrm{H} 2$ and $\mathrm{H} 3$ were evaluated using the Chi-square test, provided that the conditions for its implementation are met (number of respondents in each type of response more than 5 ; ....). Differences between groups of respondents by the business sector are significant if the $\mathrm{p}$-value of the Chi-square test is less than the level of significance $(\alpha=0.05)$. Hypotheses $\mathrm{H} 4$ and $\mathrm{H} 5$ were evaluated using the Z-score in order to compare positive attitudes among respondents according to the business sector separately in the surveyed research countries (CR, SR). The differences between the positive attitudes of the respondents according to the business sector are significant if the $\mathrm{p}$-value of the Z-score is less than $\alpha=0.05$. The statistical-analytical software SPSS Statistics was used to evaluate the formulated research hypotheses.

The overall structure of respondents $(n=822)$ according to their demographic characteristics (CR/SR):

- respondent's highest level of education: $231 / 77(50.9 \% / 20.9 \%)$ secondary education, 34/21 $(7.5 \% / 5.7 \%)$ bachelor's university education, 168/234 (37.0\% / 63.6\%) master's / engineering university education, $21 / 36(4.6 \% / 9.8 \%)$ doctoral university education;

- gender of respondent: 323/253 male (71.1\%/68.8\%) and 131/115 (28.9\%/31.2\%) female;

- age of respondent: $69 / 66(15.2 \% / 17.9 \%)$ age up to 35 years, $106 / 79(23.3 \% / 21.5 \%)$ age from 36 - 45 years, $122 / 106(26.9 \% / 28.8 \%)$ age from 46 to 55 years, $157 / 117(34.6 \% / 31.8 \%)$ age over 55 years;

- relation of education to the national economic sector of business: $171 / 138(37.7 \% / 37.5 \%)$ yes, entrepreneurs in the area I studied, 158/140 (34.8\%/38.0\%) are to some extent related (some business processes related to the area I studied), 125/90 (27.5\%/24.5\%) unrelated;

- respondent's job position in the company: 100/83 (22.0\%/22.6\%) I am the owner of the company; $354 / 285(78.0 \% / 77.4 \%)$ I am a manager in a company.

\section{Results}

The structure of respondents according the business sector in the CR/SR (\%) is: 133/107 (29.3/29.1) services (SC); 91/76 (20.1/20.7) retailing (R); 79/70 (17.4/19.0) manufacturing (M); 63/41 (13.9/11.1) construction (C); $11 / 15(2.4 / 4.1)$ tourism (T); $11 / 8(2.4 / 2.2)$ agriculture (A); 10/10 (2.2/2.7) transportation (TR); 56/41 (12.3/11.1) another area of entrepreneurship (AA). The authors compare the attitudes of respondents between two groups of respondents in the CR and SR (454/368 is 100\%): 133/107 (29.3\%/29.1\%) services (SC) and 321/261 (70.7\%/70.9\%) other companies.

Table 1 summarises the results of the assessment of the management risk sources of respondents according to and their nationality. 


\section{JOURNAL OF TOURISM AND SERVICES}

Issue 21, volume 11, ISSN 1804-5650 (Online) www.jots.cz

Table 1. Evaluation of respondents' attitude to the management risk sources

\begin{tabular}{|c|c|c|c|c|c|c|c|c|}
\hline \multirow{2}{*}{$\begin{array}{l}\text { Type of } \\
\text { answers }\end{array}$} & \multicolumn{4}{|c|}{ Czech republic } & \multicolumn{4}{|c|}{ Slovak republic } \\
\hline & MR1 & MR2 & MR3 & MR4 & MR1 & MR2 & MR3 & MR4 \\
\hline $\mathbf{A} 1+\mathbf{A} 2$ & 311 & 330 & 374 & 402 & 268 & 293 & 321 & 323 \\
\hline$(\%)$ & $68.5 \%$ & $72.7 \%$ & $82.4 \%$ & $88.5 \%$ & $72.8 \%$ & $79.6 \%$ & $87.2 \%$ & $87.8 \%$ \\
\hline A3 & 74 & 79 & 50 & 38 & 54 & 59 & 44 & 41 \\
\hline$(\%)$ & $16.3 \%$ & $17.4 \%$ & $11.0 \%$ & $8.4 \%$ & $14.7 \%$ & $16.0 \%$ & $12.0 \%$ & $11.1 \%$ \\
\hline $\mathrm{A} 4+\mathrm{A} 5$ & 69 & 45 & 30 & 14 & 46 & 16 & 3 & 4 \\
\hline$(\%)$ & $15.2 \%$ & $9.9 \%$ & $6.6 \%$ & $3.1 \%$ & $12.5 \%$ & $4.4 \%$ & $0.8 \%$ & $1.1 \%$ \\
\hline TC & \multicolumn{4}{|c|}{74.956} & \multicolumn{4}{|c|}{81.021} \\
\hline$P$ - value & \multicolumn{4}{|c|}{$<0.001$} & \multicolumn{4}{|c|}{$<0.001$} \\
\hline
\end{tabular}

Source: own data collection.

The results (see Table 1) showed that up to $88.5 \%$ of respondents fully agreed with the statement (A1) that the owner (or top manager) should regularly evaluate the performance of his subordinates and motivate them to innovate work practices in tourism. In the Slovak Republic, the number of respondents is slightly smaller $(87.8 \%)$. The most significant differences between respondents by nationality are in the attitude to the use of participatory management (involvement of employees in decision-making). The number of Slovak respondents with an entirely positive attitude to the statement is $79.9 \%$ compared to $72.7 \%$ of Czech respondents. There are statistically significant differences between the respondents' attitudes to selected statements on the management of the company in CR (TC $=74.956$; p-value $<0.001)$. There are statistically significant differences between the respondents' attitudes towards selected sources of strategic risk in the Slovak Republic (TC $=81.021$; p-value $<0.001)$. Statistical hypotheses H1_CR and H1_SR are rejected.

The structure of the entrepreneurs' answers (source MR1 of management risk) according to the business sector (SC, OC) and nationality (CR; SR) were: CR: (OC/SC) - A1 - 159/45; A2 - 70/37; A3 - 46/28; A4 - 26/13; A5 - 20/10 and SR: (OC/SC) - A1 - 116/39; A2 - 76/37; A3 - 37/17; A4 27/10; A5 - 5/4. The following Table 2 summarises the results of the assessment of the management risk' source (MR1) of respondents according to the business sector and their nationality.

Table 2. Evaluation of respondents' attitude to the management risk source MR1

\begin{tabular}{|c|c|c|c|c|}
\hline \multirow{3}{*}{ MR1 } & \multicolumn{2}{|c|}{ CR } & \multicolumn{2}{|c|}{ SR } \\
\hline & \multicolumn{2}{|c|}{ Business sector } & \multicolumn{2}{|c|}{ Business sector } \\
\hline & OC & SC & OC & SC \\
\hline $\mathbf{A} 1+\mathbf{A} 2$ & 229 & 82 & 192 & 76 \\
\hline$(\%)$ & $71.4 \%$ & $61.7 \%$ & $73.6 \%$ & $71.0 \%$ \\
\hline A3 & 46 & 28 & 37 & 17 \\
\hline$(\%)$ & $14.3 \%$ & $21.1 \%$ & $14.2 \%$ & $15.9 \%$ \\
\hline A4 + A5 & 46 & 23 & 32 & 14 \\
\hline$(\%)$ & $14.3 \%$ & $17.2 \%$ & $12.2 \%$ & $13.1 \%$ \\
\hline SUM & 321 & 133 & 261 & 107 \\
\hline TC & \multicolumn{2}{|c|}{1.236} & \multicolumn{2}{|c|}{0.421} \\
\hline p-value & \multicolumn{2}{|c|}{0.539} & \multicolumn{2}{|c|}{0.810} \\
\hline
\end{tabular}

Note: OC - Other companies; SC - Service companies; TC - Test criterion of Chi-square test.

The results (Table 2) show that $61.7 \%$ of Czech and $71 \%$ of Slovak SMEs in the service sector stated that they run the company (business) intensively (more than 8 hours a day). The business sector is 


\section{JOURNAL OF TOURISM AND SERVICES}

Issue 21, volume 11, ISSN 1804-5650 (Online)

www.jots.cz

a statistically significant factor in the assessment of consensus on the source of MR1 management risk among entrepreneurs in the service sector and other SMEs in CR $(\mathrm{Z}$-score $=2,022 ; \mathrm{p}$-value $=0.044)$. We reject the H4_MR1 hypothesis. The business sector is not a statistically significant factor in the assessment of consensus on the source of MR1 management risk among entrepreneurs in the services sector and other SMEs in the Slovak Republic (Z-score $=0.497$; p-value $=0.617)$. We accept hypothesis H5_MR1. Hypotheses H2_MR1 and H3_MR1 are accepted because there are no significant differences between the selected sectors in the structure of responses to MR1 in CR (Chi-square test $=4.438$; $\mathrm{p}$ value $=0.109)$ or in SR (Chi-square test $=0.260 ; \mathrm{p}$-value $=0.878)$.

The structure of the entrepreneurs' answers (source MR2 of management risk) according to the business sector (SC, OC) and nationality (CR; SR) were: CR: (OC/SC) - A1 - 97/53; A2 - 137/43; A3 - 54/25; A4 - 24/9; A5 - 9/3 and SR: (OC/SC) - A1 -89/37; A2 - 1195/48; A3 - 41/18; A4 - 11/4; A $5-1 / 0$. The following Table 3 summarises the results of the assessment of the management risk' source (MR2) of respondents according to the business sector and their nationality.

Table 3. Evaluation of respondents' attitude to the management risk source MR2

\begin{tabular}{|c|c|c|c|c|}
\hline \multirow{3}{*}{ MR2 } & \multicolumn{2}{|c|}{ CR } & \multicolumn{2}{|c|}{ SR } \\
\hline & \multicolumn{2}{|c|}{ Business sector } & \multicolumn{2}{|c|}{ Business sector } \\
\hline & OC & SC & OC & SC \\
\hline $\mathbf{A} 1+\mathbf{A} 2$ & 234 & 96 & 208 & 85 \\
\hline$(\%)$ & $72.9 \%$ & $72.2 \%$ & $79.7 \%$ & $79.5 \%$ \\
\hline A3 & 54 & 25 & 41 & 18 \\
\hline$(\%)$ & $16.8 \%$ & $18.8 \%$ & $15.7 \%$ & $16.8 \%$ \\
\hline A4 + A5 & 33 & 12 & 12 & 4 \\
\hline$(\%)$ & $10.3 \%$ & $9.0 \%$ & $4.6 \%$ & $3.7 \%$ \\
\hline SUM & 321 & 133 & 261 & 107 \\
\hline TC & \multicolumn{2}{|c|}{0.367} & \multirow{2}{*}{\multicolumn{2}{|c|}{$\begin{array}{l}\text { The prerequisite for performing testing } \\
\text { is not met }\end{array}$}} \\
\hline p-value & & & & \\
\hline
\end{tabular}

Note: OC - Other companies; SC - Service companies; TC - Test criterion of Chi-square test.

The results (Table 3) show that $72.2 \%$ of Czech and $79.5 \%$ of Slovak SMEs in the service sector use a participatory management style in the company (i.e. the involvement of employees in decision making. The business sector is not a statistically significant factor in the assessment of consensus on the source of MR2 management risk among entrepreneurs in the service sector and other SMEs in the CR $(Z$-score $=0.156 ; \mathrm{p}$-value $=0.873)$, nor in the SR $(Z$-score $=0.055 ; \mathrm{p}$-value $=0.960)$. We accept hypotheses H4_MR2 and H5_MR2. We accept the H2_MR2 hypotheses because there are no significant differences in the structure of MR2 responses in CR between the selected sectors (Chi-square test $=$ 0.367; p-value $=0.832$ ). Due to the non-fulfilment of the condition for performing the test, it is not possible to evaluate the hypothesis H3_MR2 in the SR.

The structure of the entrepreneurs' answers (source MR3 of management risk) according business sector (SC, OC) and nationality (CR; SR) were: CR: (OC/SC) - A1 - 185/79; A2 - 77/33; A3 - 38/12; A4 - 12/8; A5 - 9/1 and SR: (OC/SC) - A1 - 147/66; A2 - 79/29; A3 - 32/12; A4 - 2/0; A5 $-1 / 0$. The following Table 4 summarises the results of the assessment of the management risk' source (MR3) of respondents according to the business sector and their nationality.

The results (Table 4) show that $84.2 \%$ of Czech and $88.8 \%$ of Slovak SMEs in the service sector agree with the statement $(\mathrm{A} 1+\mathrm{A} 2)$ that human capital is the most important in the company. The business sector is not a statistically significant factor in the assessment of consensus on the source of MR3 management risk among entrepreneurs in the service sector and other SMEs in the CR (Z-score = $-0.660 ; \mathrm{p}$-value $=0.509)$, nor the SR $(Z$-score $=-0.573 ; \mathrm{p}$-value $=0.569)$. We accept hypotheses H4_MR3 


\section{JOURNAL OF TOURISM AND SERVICES}

Issue 21, volume 11, ISSN 1804-5650 (Online)

www.jots.cz

and H5_MR3. We accept the H2_MR3 hypotheses because there are no significant differences in the structure of MR2 responses in CR between the selected sectors (Chi-square test $=0.761$; p-value $=0.684$ ). Due to the non-fulfilment of the condition for performing the test, it is not possible to evaluate the hypothesis H3_MR3 in the Slovak Republic.

Table 4. Evaluation of respondents' attitude to the management risk source MR3

\begin{tabular}{|c|c|c|c|c|}
\hline \multirow{3}{*}{ MR3 } & \multicolumn{2}{|c|}{ CR } & \multicolumn{2}{|c|}{ SR } \\
\hline & \multicolumn{2}{|c|}{ Business sector } & \multicolumn{2}{|c|}{ Business sector } \\
\hline & OC & SC & OC & SC \\
\hline $\mathrm{A} 1+\mathbf{A} 2$ & 262 & 112 & 226 & 95 \\
\hline$(\%)$ & $81.7 \%$ & $84.2 \%$ & $86.6 \%$ & $88.8 \%$ \\
\hline A3 & 38 & 12 & 32 & 12 \\
\hline$(\%)$ & $11.8 \%$ & $9.0 \%$ & $12.3 \%$ & $11.2 \%$ \\
\hline A4 + A5 & 21 & 9 & 3 & 0 \\
\hline$(\%)$ & $6.5 \%$ & $6.8 \%$ & $1.1 \%$ & $0.0 \%$ \\
\hline SUM & 321 & 133 & 261 & 107 \\
\hline TC & \multicolumn{2}{|c|}{0.761} & \multirow{2}{*}{\multicolumn{2}{|c|}{$\begin{array}{l}\text { The prerequisite for performing testing } \\
\text { is not met }\end{array}$}} \\
\hline p-value & \multicolumn{2}{|c|}{0.684} & & \\
\hline
\end{tabular}

Note: OC - Other companies; SC - Service companies; TC - Test criterion of Chi-square test.

The structure of the entrepreneurs' answers (source MR4 of management risk) according business sector (SC, OC) and nationality (CR; SR)were: CR: (OC/SC) - A1 - 179/68; A2 - 107/48; A3 - 27/11; A 4 - 5/3; A 5 - $3 / 3$ and SR: (OC/SC) - A 1 - 134/52; A2 - 92/45; A3 - 31/10; A4 - 3/0; A5 - 1/0. The following Table 5 summarises the results of the assessment of the management risk' source (MR4) of respondents according to the business sector and their nationality.

Table 5. Evaluation of respondents' attitude to the management risk source MR4

\begin{tabular}{|c|c|c|c|c|}
\hline \multirow{3}{*}{ MR5 } & \multicolumn{2}{|c|}{ CR } & \multicolumn{2}{|c|}{ SR } \\
\hline & \multicolumn{2}{|c|}{ Business sector } & \multicolumn{2}{|c|}{ Business sector } \\
\hline & OC & $\mathrm{SC}$ & OC & SC \\
\hline $\mathbf{A} 1+\mathbf{A} 2$ & 286 & 116 & 226 & 97 \\
\hline$(\%)$ & $89.1 \%$ & $87.2 \%$ & $86.6 \%$ & $90.7 \%$ \\
\hline A3 & 27 & 11 & 31 & 10 \\
\hline$(\%)$ & $8.4 \%$ & $8.3 \%$ & $11.9 \%$ & $9.3 \%$ \\
\hline $\mathrm{A} 4+\mathrm{A} 5$ & 8 & 6 & 4 & 0 \\
\hline$(\%)$ & $2.5 \%$ & $4.5 \%$ & $1.5 \%$ & $0.0 \%$ \\
\hline SUM & 321 & 133 & 261 & 107 \\
\hline TC & \multicolumn{2}{|c|}{1.283} & \multirow{2}{*}{\multicolumn{2}{|c|}{$\begin{array}{l}\text { The prerequisite for performing testing } \\
\text { is not met }\end{array}$}} \\
\hline p-value & \multicolumn{2}{|c|}{0.527} & & \\
\hline
\end{tabular}

Source: own data collection

Note: OC - Other companies; SC - Service companies; TC - Test criterion of Chi-square test.

The results (Table 5) show that $87.2 \%$ of Czech and $90.7 \%$ of Slovak SMEs in the service sector agree with the statement $(\mathrm{A} 1+\mathrm{A} 2)$ that the business owner (or top manager) should regularly evaluate the performance of their subordinates and motivate them to innovate workflows. The business sector is not a statistically significant factor in the assessment of consensus on the source of MR4 management risk among entrepreneurs in the service sector and other SMEs in the CR $(Z$-score $=0.572$; $\mathrm{p}$-value $=$ 


\section{JOURNAL OF TOURISM AND SERVICES}

Issue 21, volume 11, ISSN 1804-5650 (Online)

www.jots.cz

0.569), nor in the SR (Z-score $=-1.081 ;$ p-value $=0.280)$. We accept hypotheses H4_MR4 and H5_MR4. We accept the H2_MR4 hypotheses because there are no significant differences in the structure of MR2 responses in CR between the selected sectors (Chi-square test $=1.283$; $\mathrm{p}$-value $=0.527)$. Due to the nonfulfilment of the condition for performing the test, it is not possible to evaluate the hypothesis H3_MR4 in the SR.

\section{Discussion}

The case study demonstrated the following findings. There are significant differences between Czech and Slovak respondents in the service business sector in the statement that I manage more than 8 hours a day (71\% of SMEs in services in the Slovak Republic/61.7\% of SMEs in services in the Czech Republic). There are no significant differences between respondents in other business sectors to the above statement $(73.6 \%$ of SMEs in services in the SR/71.4\% of SMEs in services in the CR). At the stage when the firm has limited financial resources, building relationships with clients, stakeholders is the primary task of the owner (founding) of the company. Much of the success of a business in moving to the next stage depends on skills, experience, and how they are used in managing people (Muda \& Rahman, 2016). It is important to note that teach stage of the firm's activities requires specific kills. Thus, the owners can use their knowledge and strengths, or at some stages delegate the management of the process to managers (employees) who have the necessary experience and skills (Mamabolo \& Myres, 2020).

Eight out of ten respondents, regardless of nationality or business sector, fully agreed with the statement that they consider human capital to be the most important in the company. Significant differences were not confirmed either between countries or between business sectors. The findings are consistent with a large amount of existing literature. For example, according to Sardo et al. (2018), human capital is of great value, especially for SMEs working in the service sector. Since it is high-quality employees who know and love their job that can influence the disposition of customers and the increase of the service provided by the company. Our findings are supported by the He et al. (2019) research, which indicates that SMEs place particular emphasis on human capital as a way of protecting company innovation and a way of developing a brand. At this time, large companies often focus on the development of R\&D and intellectual property; financial investments in these areas are expensive. The data also agree with Muda \& Rahman (2016), which states that human capital is an essential tool for transforming information into valuable data that positively affects the operation of the firm. The professional skills and experience of employees, their educational level and motivation are essential. That is why companies pay much attention to improving the qualifications of their employees, organizing courses and training (Agostini et al., 2017), and taking steps to increase engagement and motivation (Andersén, 2017; Wach et al., 2016).

There are no significant differences in the use of participatory business management between companies in the services sector and other companies in the CR or the SR. The influence of the business sector on the involvement of employees in the management of the company was not confirmed in the business environment in the CR or the SR. It is noteworthy that the data obtained from the article of Zehir et al. (2016), which claims that encouraging the active participation of employees in the activities of the company has a positive effect on its efficiency. Moreover, for the employee, it is a stimulating indicator that his opinion is valuable, which leads to his proactive influence in the work of the company. For example, Andersén's (2017) study, cited in the existing literature, argues that while employee involvement in decision making can lead to profits and benefits for the company, it is essential that managers do not forget about role ambiguity, which can lead to negative consequences in decision making. A similarly more cautious view of involving employees in management and decision-making within the company is shared by Zhang et al. (2017). It is vital that when making decisions, they are focused on the result, and with the participation of several departments does not lead to some uncertainty. 


\section{JOURNAL OF TOURISM AND SERVICES}

Issue 21, volume 11, ISSN 1804-5650 (Online)

www.jots.cz

Interestingly, the data presented in the study is different from some of the Mesuat al. (2015) studies for the Netherlands where it is noted that for industrial SMEs, a directive leadership style works better than a participatory leadership style. While a participatory leadership style leads to subordinate commitment, in small manufacturing firms where production is less automated, clear orders and leadership from a company that knows the owner's job is essential. Also, a participatory leadership style can look like a weakness in the eyes of subordinates when the owner is "forced" to ask for advice.

On average, nine out of ten respondents (CR: OC $=89.1 \%$, SC $=87.2 \%$; SR: OC $=86.6 \%$, SC $=90.7 \%$ ), regardless of nationality or business sector, fully agreed with the statement that the business owner (manager) should regularly evaluate the performance of its subordinates and motivate them to innovate their work practices. Significant differences were not confirmed between respondents by nationality and also between business sectors in selected countries. The data agree with the study, where O'Neillet et al. (2016) note that since the efficiency of the company is aimed at achieving profit, the measurement of efficiency should be objective, based on indicators selected in the company and be managed by the owner or top management of the company. The required level of control can also be carried out by a quality management system based on quality assurance reports, timely management and quality workflow. Meanwhile, Pešaljet et al. (2018) point out that the control of the productivity of industrial SMEs should be based on such values as an open culture, the sharing of successes and failures, and a low power distance. The primary control is carried out by the owner of the company (it is he who is the key link in performance control) or the leading manager, which is consistent with the results of our study. Often the key performance indicators are financial indicators - profitability, product turnover, liquidity. Performance systems are installed to provide monitoring, providing real-time information. This allows owners to increase the involvement of employees in the company's processes and their commitment. Some studies note that employee productivity is highly dependent on the internal climate of the company, perceptions of the firm's practices, and overall job satisfaction (Muda \& Rahman, 2016). Thus, motivated and satisfied employees require less control over their activities.

\section{Conclusion}

The aim of the article was compared important factors of management between SMEs in the service sector and SMEs in other sectors of entrepreneurship separately in the Czech Republic and the Slovak Republic.

The results of the case study brought common and different features between respondents according to nationality (CR and SR) and also between selected groups according to the business sector (SMEs in the field of services and other SMEs) separately in the examined countries. There are significant differences between companies in the service sector and other companies in the CR. Entrepreneurs in services are significantly less engaged in entrepreneurship $(61.7 \%)$ than entrepreneurs from other business sectors $(71.4 \%)$. In the Slovak Republic, there are no significant differences between these groups of SMEs. As many as eight out of ten respondents consider human capital to be the most important for a company. As many as nine out of ten respondents say that a business owner (manager) should regularly evaluate the performance of their subordinates and motivate them to innovate their work practices. There are no significant differences between the groups of respondents (nationality, business sector) on the above statements.

One of the limits of the research is the fact that data collection from small and medium-sized enterprises in the Czech and Slovak Republics took place for the most part before the outbreak of the COVID-19 virus pandemic. Also, the study compares only two Central European countries. The percentage of SMEs in selected business sectors is comparable to the total number of SMEs in the given sectors (and countries). However, in the future, it is necessary to verify the achieved results on another sample of respondents. 


\section{JOURNAL OF TOURISM AND SERVICES}

Issue 21, volume 11, ISSN 1804-5650 (Online)

www.jots.cz

The following research activities of the authors will focus on finding significant differences in the perception of economic, financial, technological, legal, legislative factors between small and mediumsized enterprises in the services segment and other business sectors in selected Central European countries.

\section{Acknowledgments}

The research was supported by the Research and Development Agency GAAA under contract No. 21/2020: 'Management, business risk and firm bankruptcy in the segment of SMEs.' This research was co-funded by grants from the Ministry of Education and Science of Ukraine (No 0120U102002, No0120U102001).

\section{References}

1. Agostini, L., Nosella, A., \& Filippini, R. (2017). Does intellectual capital allow improving innovation performance? A quantitative analysis in the SME context. Journal of Intellectual Capital, 18(2), 400-418. https://doi.org/10.1108/jic-05-2016-0056

2. Andrews, R., Beynon, M., \& Genc, E. (2017). Strategy Implementation Style and Public Service Effectiveness, Efficiency and Equity. Administrative Sciences, 7(1), 4. doi: https://doi.org/10.3390/admsci7010004.

3. Ahmed, I., Sultana, I., Paul, S. K., \& Azeem, A. (2013). Employee performance evaluation: A fuzzy approach. International Journal of Productivity and Performance Management, 62(7), 718-734. https://doi.org/10.1108/IJPPM-01-2013-0013

4. Andersén, J. (2017). What about the employees in entrepreneurial firms? A multi-level analysis of the relationship between entrepreneurial orientation, role ambiguity, and social support. International Small Business Journal: Researching Entrepreneurship, 35(8), 969-990. https://doi.org/10.1177/0266242617690797

5. Androniceanu, A., \& Tvaronavičienè, M. (2019). Developing a holistic system for social assistance services based on effective and sustainable partnerships. Administratie si Management Public, 33, 103118. https://doi.org/10.24818/amp/2019.33-06.

6. Argyle, M., \& Lu, L. (1990). Happiness and social skills. Personality and Individual Differences, 11(12), 1255-1261. https://doi.org/10.1016/0191-8869(90)90152-H

7. Awiagah, R., Kang, J., \& Lim, J. I. (2016). Factors affecting e-commerce adoption among SMEs in Ghana. Information Development, 32(4). https://doi.org/10.1177/0266666915571427

8. Behun, M., Gavurova, B., Tkacova, A., \& Kotaskova, A., (2018). The Impact of the Manufacturing Industry on the Economic Cycle of European Union Countries. Journal of Competitiveness, 10(1), 23-39. https://doi.org/10.7441/joc.2018.01.02

9. Belas, J., Smrcka, L., Gavurova, B., \& Dvorsky, J. (2018). The Impact of Social and Economic Factors in the Credit Risk Management of SME. Technological and Economic Development of Economy, Volume 24, Issue 3: 1215-1230. https://doi.org/10.3846/tede.2018.1968

10. Bilan, Y., Gavurova, B., Stanislaw, G., \& Tkacova, A. (2017). The Composite Coincident Indicator (CCI) for Business Cycles. Acta Polytechnica Hungarica, 14(7), 71-90. https://doi.org/10.12700/aph.14.7.2017.7.5

11. Biondi, V., Iraldo, F., \& Meredith, S. (2002). Achieving sustainability through environmental innovation: The role of SMEs. International Journal of Technology Management, 24(5-6), 612-626. https://doi.org/10.1504/IJTM.2002.003074

12. Bocconcelli, R., Cioppi, M., \& Pagano, A. (2017). Social media as a resource in SMEs' sales 


\section{JOURNAL OF TOURISM AND SERVICES}

Issue 21, volume 11, ISSN 1804-5650 (Online)

www.jots.cz

process. Journal of Business and Industrial Marketing, 32(5), 693-709. https://doi.org/10.1108/JBIM11-2014-0244

13. Brătianu, C., \& Anagnoste, S. (2011). The role of transformational leadership in mergers and acquisitions in emergent economies. Management \& Marketing, 6(2), 319-326.

14. Cengiz Toklu, M., \& Taşkin, H. (2017). Performance evaluation of small-medium enterprises based on management and organization. Acta Physica Polonica A, 132(3), 994-998. https://doi.org/10.12693/APhysPolA.132.994

15. Çera, G. Meço, M., Çera, E., \& Maloku, S. (2019). The effect of institutional constraints and business network on trust in government: an institutional perspective. Administratie si Management Public, 33, 6-19. https://doi.org/10.24818/amp/2019.33-01.

16. Cieślik, A., \& Michałek, J. J. (2018). Process and product innovations, multi-product status and export performance: firm-level evidence from V-4 countries. Equilibrium. Quarterly Journal of Economics and Economic Policy, 13(2), 233-250. https://doi.org/10.24136/eq.2018.012.

17. Chung, T.A., \& Tseng, C.Y. (2019). The knowledge intensity and the economic performance in Taiwan's knowledge intensity business services, Economic Research-Ekonomska Istrą̌ivanja, 32(1), 797-811. https://doi.org/10.1080/1331677X.2019.1583586.

18. Day, C., Elliot, B., \& Kington, A. (2005). Reform, standards and teacher identity: Challenges of sustaining commitment. Teaching and Teacher Education, 21(5), 563-577. https://doi.org/10.1016/j.tate.2005.03.001

19. De Bruyckere, S., Verplancke, F., Everaert, P., Sarens, G., \& Coppens, C. (2020). The Importance of Mutual Understanding Between External Accountants and Owner-Managers of SMEs. Australian Accounting Review, 30(1), 4-21. https://doi.org/10.1111/auar.12251

20. Dima, A.M., Begu, L., Vasilescu, M.D., \& Maassen, M.A. (2018). The Relationship between the Knowledge Economy and Global Competitiveness in the European Union. Sustainability 10, 1706.

21. Ferreira, A., \& Franco, M. (2019). The influence of strategic alliances on human capital development: A study applied to technology-based SMEs. EuroMed Journal of Business, 15(1), 65 85. https://doi.org/10.1108/EMJB-04-2019-0052

22. Gebert, D., Boerner, S., \& Lanwehr, R. (2003). The risks of autonomy: Empirical evidence for the necessity of a balance management in promoting organizational innovativeness. Creativity and Innovation Management, 12(1), 41-49. https://doi.org/10.1111/1467-8691.00267

23. Gluchman, V. (2019). Human Dignity as the Essence of Nussbaum's Ethics of Human Development. Philosophia,47(4), pp. 1127-1140. https://doi.org/10.1007/s11406-0034-2

24. Gluchman, V. (2018). Nussbaum's philosophy of education as the foundation for human development. Human Affairs 2018, 28(3), pp. 328-338. https://doi.org/10.1515/humaff-20180026

25. He, Q., Guaita-Martínez, J.M.,\& Botella-Carrubi, D. (2019). How brand equity affects firm productivity: The role of R\&D and human capital, Economic Research-Ekonomska Istraživanja, 32(1). https://doi.org/10.1080/1331677X.2019.1686045.

26. Hernández-Perlines, F., Ibarra Cisneros, M.A., Ribeiro-Soriano, D., \& Mogorrón-Guerrero, H. (2019). Innovativeness as a determinant of entrepreneurial orientation: analysis of the hotel sector, Economic Research-Ekonomska Istră̌ivanja, https://doi.org/10.1080/1331677X.2019.1696696.

27. Hudakova, M., Masar, M., Luskova, M., \& Patak M.R. (2018). The Dependence of Perceived Business Risks on the Size of SMEs. Journal of Competitiveness, 10(4), 54-69. https://doi.org/10.7441/joc.2018.04.04

28. Hvolkova, L., Klement, L., Klementova, V., \& Kovalova, M. (2019). Barriers Hindering Innovations in Small and Medium-Sized Enterprises. Journal of Competitiveness, 11(2), 51-67. https://doi.org/10.7441/ joc.2019.02.04

29. Ion, P., \& Andreea, Z. (2008). Use Of Ict In Smes Management Within The Sector Of Services. Annals of the University of Oradea: Economic Science, 4(1), 481-487. 


\section{JOURNAL OF TOURISM AND SERVICES}

Issue 21, volume 11, ISSN 1804-5650 (Online)

www.jots.cz

30. Isonzo, V. (2006). Corporate Entrepreneurship, 45(3), 407-427. https://doi.org/10.1002/hrm

31. Kaur, N., \& Sood, S. K. (2017). A game theoretic approach for an IoT-based automated employee performance evaluation. IEEE Systems Journal, 11(3), 1385-1394. https://doi.org/10.1109/JSYST.2015.2469102

32. Ključnikov, A., Civelek, M., Čech, P., \& Kloudová, J. (2019). Entrepreneurial orientation of SMEs' executives in the comparative perspective for Czechia and Turkey. Oeconomia Copernicana, 10(4), 773-795. https://doi.org/10.24136/oc.2019.035.

33. Ključnikov, A., Belás, J., \& Smrčka, L. (2016). Risk-taking and Aggressiveness as the Significant Part of the Entrepreneurial Orientation of SMEs: Case of the Czech Republic. Polish Journal of Management Studies, Volume 14, No 1, pp. 129-139. https://doi.org/10.17512/pjms.2016.14.1.12

34. Koisova, E., Masarova, J., \& Habanik, J. (2018). Regional Differences in the Labor Market in Slovakia and the Czech Republic. Journal of Competitiveness, Vol. 10, Issue 2, pp. 104 - 117. DOI: 10.7441/joc.2018.02.07

35. Kot, S., Ul Haque, A., \& Baloch, A. (2020). Supply chain management in SMEs: Global perspective. Montenegrin Journal of Economics, 16 (1), pp. 87-104. https://doi.org/10.14254/18005845/2020.16-1.6

36. Kotaskova, A., Belas, J., Bilan, Y., \& Ajaz Khan, K. (2020). Significant Aspects of Managing Personnel Risk in the SME Sector. Management \& Marketing. Challenges for the Knowledge Society, 15(2), 203-218. https://doi.org/10.2478/mmcks-2020-0013

37. Kotaskova, A., \& Rozsa, Z. (2018). The Impact of Selected Factors on the Quality of Business Environment Assessment in the Czech Republic and the Slovak Republic. International Journal of Entrepreneurial Knowledge, 6(2), 71-80. https://doi.org/10.2478/ijek-2018-0015

38. Kozubíková, L., Belás, J., Ključnikov, A., \& Virglerová, Z. (2015). Differences in approach to selected constructs of entrepreneurail orientation in SME segment regarding the selected sociodemographic factors. Transformation in Business nad Economic, Vol. 14, No. 3C(36C), pp. 333-355.

39. Kubíčková , K., \& Hodžić, M. (2019). The evaluation of project management practices in the Czech social enterprises, Economic Research-Ekonomska Istraživanja, 32(1). https://doi.org/10.1080/1331677X.2018.1553679.

40. Kwaku Amoah, S. (2018). The Role of Small and Medium Enterprises (SMEs) to Employment in Ghana. International Journal of Business and Economics Research, 7(5), 151. https://doi.org/10.11648/j.ijber.20180705.14

41. Leake, C., Goodwin, P., \& Wright, G. (1998). Decision Analysis for Management Judgment (2nd Edn). In The Journal of the Operational Research Society (Vol. 49, Issue 10). https://doi.org/10.2307/3010535

42. Lewandowska, A., \& Stopa, M. (2019). Do SME's innovation strategies influence their effectiveness of innovation? Some evidence from the case of Podkarpackie as peripheral region in Poland. Equilibrium. Quarterly Journal of Economics and Economic Policy, 14(3), 521-536. https://doi.org/10.24136/eq.2019.025

43. Mačerinskienè, I., \& Survilaite, S. (2019). Company's intellectual capital impact on market value of Baltic countries listed enterprises. Oeconomia Copernicana, 10(2), 309-339. https://doi.org/10.24136/oc.2019.016

44. Mamabolo, A., \& Myres, K. (2020). A systematic literature review of skills required in the different phases of the entrepreneurial process. Small Enterprise Research, 0(0), 1-25. https://doi.org/10.1080/13215906.2020.1730230

45. Marvel, M. R., Davis, J. L., \& Sproul, C. R. (2016). Human Capital and Entrepreneurship Research: A Critical Review and Future Directions. Entrepreneurship: Theory and Practice, 40(3), 599626. https://doi.org/10.1111/etap.12136

46. Mesu, J., Sanders, K., \& Riemsdijk, M. . v. a. n. (2015). Transformational leadership and organisational commitment in manufacturing and service small to medium-sized enterprises. Personnel Review, 44(6), 970-990. https://doi.org/10.1108/pr-01-2014-0020 


\section{JOURNAL OF TOURISM AND SERVICES}

Issue 21, volume 11, ISSN 1804-5650 (Online) www.jots.cz

47. Meyer, N., Molefe, K., \& De Jongh, J.J.(2018). Managerial challenges within SMEs: The case of a developing region.Polish Journal of Management Studies, 18 (2), pp. 185-196. https://doi.org/10.17512/pjms.2018.18.2.15

48. Mikalauskas, R., Statnickè, G., Habánik, J., \& Navickas, V. (2019). Managementquality evaluation of sports clubs for the disabled applying the CommonAssessment Framework (CAF). Economics and Sociology, 12(1), 329-341. https://doi.org/10.14254/2071-789X.2019/12-1/20

49. Mishchuk, H., Bilan, Y., \& Pavlushenko, L. (2016). Knowledge Management Systems: Issues In Enterprise Human Capital Management Implementation In Transition Economy. Polish Journal of Management Studies, 14(1), 163-173.

50. Muda, S., \& Rahman, M. R. C. A. (2016). Human Capital in SMEs Life Cycle Perspective. Procedia Economics and Finance, 35(October 2015), 683-689. https://doi.org/10.1016/s22125671(16)00084-8

51. Nadeem, D. M. (2012). Participative Management Style: A Tool to Enhance Quality Education. IOSR Journal of Humanities and Social Science, 4(2), 8-14. https://doi.org/10.9790/0837-0420814

52. O'Neill, P., Sohal, A., \& Teng, C. W. (2016). Quality management approaches and their impact on firms' financial performance - An Australian study. International Journal of Production Economics, 171, 381-393. https://doi.org/10.1016/j.ijpe.2015.07.015

53. Păunescu, C. (2014). Current trends in social innovation research: social capital, corporate social responsibility, impact measurement. Management \& Marketing. Challenges for the Knowledge Society, Vol. 9, No. 2, pp. 105-118.

54. Pešalj, B., Pavlov, A., \& Micheli, P. (2018). The use of management control and performance measurement systems in SMEs. International Journal of Operations \& Production Management, 38(11), 2169-2191. https://doi.org/10.1108/ijopm-09-2016-0565

55. Pisar, P., \& Bilkova, D. (2019). Controlling as a tool for SME management with an emphasis on innovations in the context of Industry 4.0. Equilibrium, 14(4), 763-785. https://doi.org/10.24136/eq.2019.035

56. Pratono, A. H. (2016). Strategic orientation and information technological turbulence. Business Process Management Journal, 22(2), 368-382. https://doi.org/10.1108/bpmj-05-2015-0066

57. Priem, R. L., Li, S., \& Carr, J. C. (2012). Insights and new directions from demand-side approaches to technology innovation, entrepreneurship, and strategic management research. Journal of Management, 38(1), 346-374. https://doi.org/10.1177/0149206311429614

58. Rahman, A., Rozsa, Z., \& Cepel, M. (2018). Trade Credit and Bank Finance - Evidence from the Visegrad Group. Journal of Competitiveness, 10(3), 132-148. https://doi.org/10.7441/joc.2018.03.09

59. Rahman, A., Belas, J., Kliestik, T., \& Tyll, L. (2017). Collateral requirements for SME loans: empirical evidence from the Visegrad countries, Journal of Business Economics and Management, 18:4, 650-675, doi: 10.3846/16111699.2017.1357050

60. Rozsa, Z., Formánek, I., Maňák, R. (2019). Determining the factors of the employees' intention to stay or leave in the Slovak's SMEs. International Journal of Entrepreneurial Knowledge, 7(2), 63-72. https://doi.org/10.12345-0011

61. Sardo, F., Serrasqueiro, Z., \& Alves, H. (2018). On the relationship between intellectual capital and financial performance: A panel data analysis on SME hotels. International Journal of Hospitality Management, 75, 67-74. https://doi.org/10.1016/j.ijhm.2018.03.001

62. Soriano, D. R., \& Castrogiovanni, G. J. (2010). The impact of education, experience and inner circle advisors on SME performance: insights from a study of public development centers. Small Business Economics, 38(3), 333-349. https://doi.org/10.1007/s11187-010-9278-3

63. Soomro, R. H., \& Aziz, F. (2015). Determining the Size of Thresholds of Small and Medium Enterprises Definition. International Journal of Management, IT and Engineering, 5(1), 63-71.

64. Spreitzer, G. M., \& Mishra, A. K. (1999). Giving up control without losing control : Trust and its substitutes' effects ... Reproduced with permission of the copyright owner . Further reproduction 


\section{JOURNAL OF TOURISM AND SERVICES}

Issue 21, volume 11, ISSN 1804-5650 (Online)

www.jots.cz

prohibited without permission . Group \& Organiation Mangement, 24(2), 155-187.

65. Tantau, A.D., Maassen, M.A., \& Fratila, L. (2018). Models for Analyzing the Dependencies between Indicators for a Circular Economy in the European Union. Sustainability, 10, 2141.

66. Wach, D., Stephan, U., \& Gorgievski, M. (2016). More than money: Developing an integrative multi-factorial measure of entrepreneurial success. International Small Business Journal: Researching Entrepreneurship, 34(8), 1098-1121. https://doi.org/10.1177/0266242615608469

67. Wang, T., Thornhill, S., \& Zhao, B. (2016). Pay-for-Performance, Employee Participation, and SME Performance. Journal of Small Business Management, 56(3), 412-434. https://doi.org/10.1111/jsbm.12268

68. Zadorozhnyi, Z. M., Sudyn, Y., \& Muravskyi, V. (2018). Goodwill assessment in enterprise management: innovative approaches using computer and communication technologies. Marketing and Management of Innovations, (4), 43-53.

69. Zehir, C., Gurol, Y., Karaboga, T., \& Kole, M. (2016). Strategic Human Resource Management and Firm Performance: The Mediating Role of Entrepreneurial Orientation. Procedia - Social and Behavioral Sciences, 235, 372-381. https://doi.org/10.1016/j.sbspro.2016.11.045

70. Zia, Y. A., \& Nouman, M. (2014). Participative Management and Job Satisfaction. SSRN Electronic Journal, 231-241. https://doi.org/10.2139/ssrn.2485702

71. Zhang, Z.-G., Yu, C.-P., \& Shen, H. (2017). The effect of organizational learning and knowledge management innovation on SMEs' technological capability. EURASLA Journal of Mathematics, Science and Technology Education, 13(8), 5475-5487. https://doi.org/10.12973/eurasia.2017.00842a

72. Žufan, J., Civelek, M., Hamarneh, I., Kmeco, L. (2020). The Impacts of Firm Characteristics on Social Media Usage Of SMEs: Evidence from the Czech Republic. International Journal of Entrepreneurial Knowledge, 8(1), 102-113. https://doi.org/10.37335/ijek.v8i1.111

\section{Brief description of Authors:}

\section{Prof. Ing. Jaroslav Belas, PhD.}

Director of Center for Applied Economic Research (CAEV), Faculty of management and economics, Tomas Bata University in Zlín, Mostní 5139, 76001 Zlín, Czech Republic, www.utb.cz, belas@utb.cz. His research is focused on Enterprise Economics, Quality of Business Environment, Risk Management, Small and Medium size Enterprise, and financial and banking sector. He published more than 70 scientific articles on database Scopus $(\mathrm{h}$-index $=16)$ and 61 scientific articles on database Web of Science (h-index $=15)$.

\section{John Amoah}

Center for Applied Economic Research (CAEV), Faculty of management and economics, Tomas Bata University in Zlín, Mostní 5139, 76001 Zlín, Czech Republic, amoah@utb.cz, www.utb.cz. He is internal PhD. Students. His research is in area of Business environment in the sector of SMEs. He published a few scientific articles on database Scopus and Web of Science $(\mathrm{h}$-index $=15)$.

\section{Assoc. Prof. Zora Petráková, PhD.}

Institute of forensic Engineering, Faculty of Civil Engineering, Slovak University of Technology, Radlinského 11, 81005 Bratislava, Slovak republic, www.stuba.sk, zora.petrakova@stuba.sk. She delivers forensic and economic assessments in difficult issues demanding expert witnesses on construction claims advanced to trials and other tribunals for resolution in behalf of citizens and organizations according to Slovak state legislation. She provides lectures in Forensic and economic engineering for full-time 
students. He published 4 scientific articles on database Scopus $(\mathrm{h}$-index $=2)$ and 3 scientific articles on database Web of Science (h-index = 2).

\section{Ing. Yana Kliuchnikava}

Second year PhD. Student at the Faculty of Management and Economics, Tomas Bata University in Zlín, Mostní 5139, 76001 Zlín, Czech Republic, www.utb.cz, kliuchnikava@utb.cz.. The topic of the diploma is the study of business risks in the SME sector. Her area of interest is articles on financial risks, risk prevention, and management in the SME sector and the study of the position and attitude of entrepreneurs to risks.

\section{Assoc. Prof. Yuriy Bilan}

He is the President of the Centre of Sociological Research. He is the Deputy Editor-in-Chief of the Economics and Sociology Journal and the Editor-in-Chief of Journal of International Studies. His research interests are labour market, entrepreneurship, energy and society. Web of Science (h-index $=$ 15), SCOPUS (h-index $=17)$. 